Bangladesh J. Plant Taxon. 19(1): 89-92, 2012 (June)

(C) 2012 Bangladesh Association of Plant Taxonomists

\title{
SEEDLING MORPHOLOGY OF FOUR SPECIES OF OCIMUM L. (LAMIACEAE) AND ITS TAXONOMIC SIGNIFICANCE
}

\author{
AJAI Kumar SingH ${ }^{1}$ \\ Department of Botany, Udai Pratap Autonomous College, Varanasi 221 002, U.P., India \\ Keywords: Seedling morphology; Ocimum; Lamiaceae; Taxonomy.
}

The genus Ocimum (family Lamiaceae, subfamily Nepetoideae, tribe Ocimeae) is cultivated for its remarkable essential oil which exhibit many herbs, culinary, perfume for herbal toiletries, aromatherapy treatment and as flavouring agent. The Ocimeae are essentially a tropical tribe and Ocimum occurs naturally in tropical America, Africa and Asia. In the state of Uttar Pradesh, India to which the present study area belongs, the genus Ocimum is represented by only 5 species, namely, Ocimum americanum L., O. basilicum L., O. gratissimum Guerke, O. kilimandscharicum Guerke and O. tenuiflorum L. (Rao, 1994; Khanna et al.,1999). Although, a number of studies have been made in recent years on phylogenetic diversity of Ocimum species (Paton et al., 2004; Singh et al., 2004; Mustfa and Badr, 2006), the significance of seedling morphology in taxonomy of Ocimum species has not been probably studied.

Seedlings of four Ocimum species, viz. O. americanum L., O. basilicum L., O. gratissimum L. and O. tenuiflorum L. were collected from different parts of Varanasi district, Uttar Pradesh, India $\left(25^{\circ} 18^{\prime} \mathrm{N}, 8^{\circ} 1^{\prime} \mathrm{E}\right)$ during the months of July to September 2008. Seeds of these four species were also collected in January and February 2009, and grown during July to August 2009 in the greenhouse of the Experimental Botanic Garden of the Department of Botany, Udai Pratap Autonomous College, Varanasi, India to ensure correct identification of seedling species. The different stages of development of each species were considered for preparing a complete description out of ten individuals. All the specimens at different leaf stages were documented in the form of herbarium sheets which have been deposited in the Herbarium, Department of Botany, Udai Pratap Autonomous College, Varanasi, Uttar Pradesh, India. The gross morphological features of seedlings were described following the terminology proposed by de Vogel (1980). For seedling description, Ahammed and Paria (1996) and Singh (2009) were followed.

Investigated species show affinity with regard to type of seedling, the morphological characters of collet, hypocotyl, paracotyledon, epicotyl and leaves. Paracotyledons of all these species are similar from a morpho-taxonomic point of view. Some morphological characters of seedlings, viz. secondary root surface, collet and number of leaf veins are found suitable to distinguish the investigated species at their juvenile stage. Findings of the present study reflect possibilities for taxonomic considerations of seedling morphology. Therefore, it is suggested that seedling morphology should be taken into consideration in a comprehensive way to distinguish the species and in solving taxonomic and phylogenetic implications.

A key to the species of Ocimum based on seedling morphology is given below.

1. Collet without distinct ring, lowermost side veins opposite in 1st leaf.

O. basilicum

Collet with distinct ring, all veins alternate in 1st leaf.

2. Secondary roots smooth.

- $\quad$ Secondary roots with parallel striations.
O. gratissimum

$\overline{{ }^{1} \text { Email: ajaiupcollege@gmail.com }}$ 
3. First leaf with 7 distinct veins, mid-vein reaches to apex.

- $\quad$ First leaf with 9 distinct veins, mid-vein not reaching to apex.

Ocimum americanum L.

Primary root fibrous, taproot; secondary roots with parallel striations. Collet distinct with brown swollen ring. Hypocotyl green, surface strigose, nearly terete. Paracotyledons 2, opposite, isocotylar, leafy, petiolate, blade deltoid, base subcordate, apex retuse, margin entire, adaxial surface dark green, abaxial surface light green, both sides strigose, venation not distinct. Epicotyl green, strigose, quadrangular. First leaf simple, opposite, exstipulate, petiolate, blade ovate, base attenuate and slightly oblique, apex acute, margin dentate, both surfaces dark green, strigose, many pits on abaxial side, 7 veins distinct, mid-vein reaches to the apex. Subsequent leaves same as that of 1st leaf.

\section{Ocimum basilicum L.}

(Fig. 1, D-F)

Primary root non-fibrous, taproot; secondary roots smooth. Collet without distinct ring, smooth. Hypocotyl purplish-green, surface pubescent, terete. Paracotyledons 2, opposite, isocotylar, leafy, petiolate, blade deltoid, base subcordate, apex retuse, margin entire, adaxial surface dark green, abaxial surface light green, both sides pubscent, venation not distinct. Epicotyl reddish-green, pubescent, quadrangular. First leaf simple, opposite, exstipulate, petiolate, leaf blade ovate, base rounded, apex acute, margin dentate, adaxial surface dark green, abaxial surface light green, both sides pubescent, many pits on abaxial side, 9 veins distinct, lowermost side veins opposite. Subsequent leaves same as that of 1st leaf.

\section{Ocimum gratissimum L.}

(Fig. 1, G-I)

Primary root non-fibrous, taproot; secondary roots smooth. Collet distinct with yellow ring, smooth. Hypocotyl green above and white below, pubescent, terete, $3.9 \mathrm{~cm}$ long at 5th leaf stage. Paracotyledons 2, opposite, isocotylar, leafy, petiolate, blade deltoid, base subcordate, apex retuse, margin entire, adaxial surface dark green, abaxial surface light green, both sides pubescent, venation not distinct. Epicotyl green, pubescent, quadrangular, $6.9 \mathrm{~cm}$ long at 5 th leaf stage. First leaf simple, opposite, petiolate, leaf blade ovate, base attenuate, apex acute, margin denticulate, adaxial surface dark green, abaxial surface light green, both surfaces pubescent, few pits on abaxial side, 7 veins distinct, all veins alternate. Subsequent leaves same as that of 1 st leaf, but leaf margin dentate after 2nd or 3rd leaf stage.

\section{Ocimum tenuiflorum L.}

(Fig. 1, J-L)

Primary root non-fibrous, taproot; secondary roots with parallel striations. Collet distinct with brown ring, smooth. Hypocotyl whitish green to purple, surface velutinose, terete, $1.6 \mathrm{~cm}$ long at 5th leaf stage. Paracotyledons 2, opposite, isocotylar, leafy, petiolate, blade deltoid, base subcordate, apex retuse, margin entire, adaxial surface dark green, abaxial surface light green, velutinous on both sides, venation not distinct. Epicotyl greenish purple, velutinoos, quadrangular, $10 \mathrm{~cm}$ long at 5th leaf stage. First leaf simple, opposite, petiolate, leaf blade ovate, base rounded and oblique, apex acute, margin remotedly dentate, adaxial surface dark green, abaxial surface light green, both sides velutinous, many pits on abaxial side, 9 veins distinct, mid-vein does not reach the apex. Subsequent leaves same as that of 1st leaf but leaf margin dentate. 


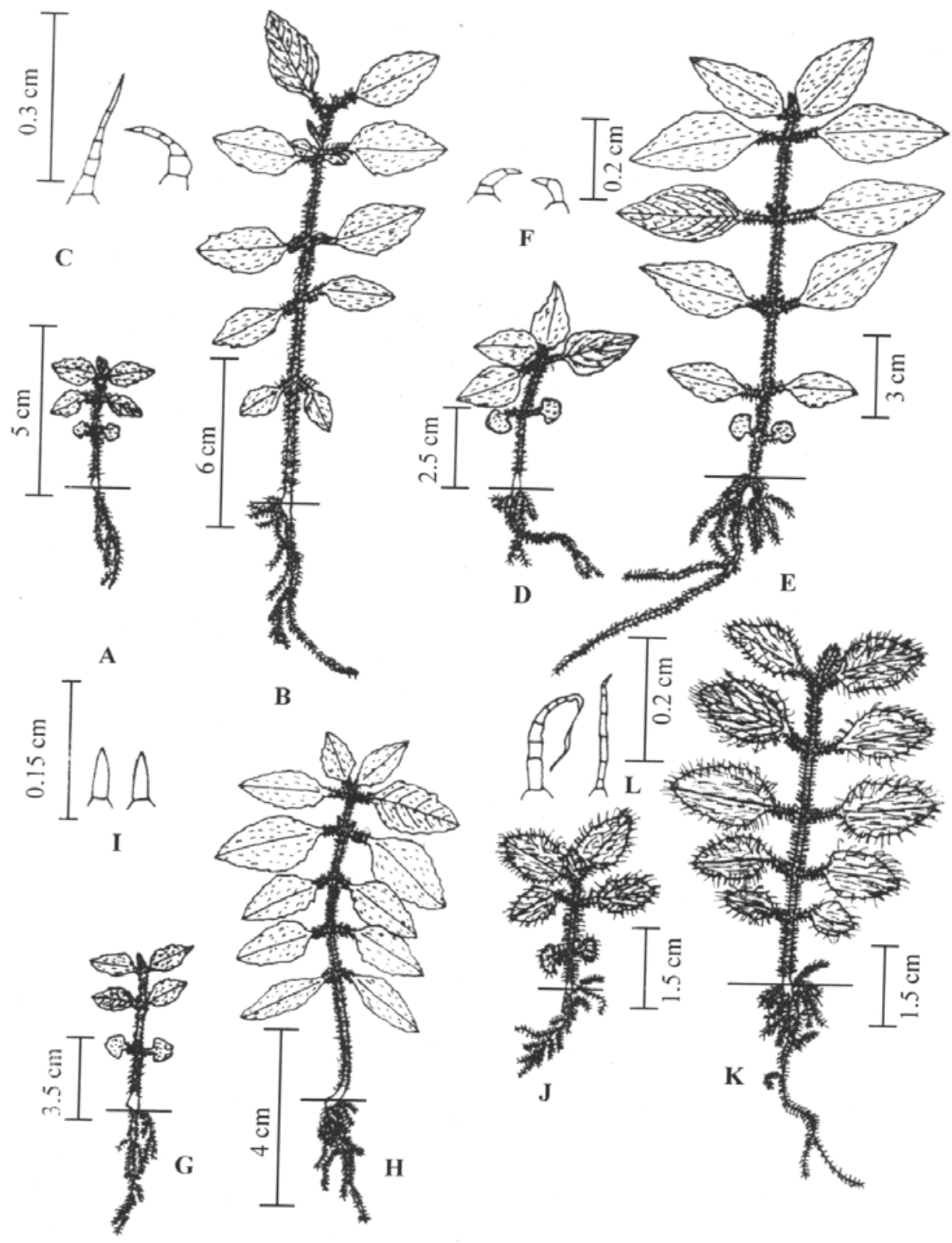

Fig. 1. Seedlings and hairs: Ocimum americanum L.- A. Second leaf stage; B. Fifth leaf stage; C. Hairs; $O$. basilicum L.- D. Second leaf stage; E. Fifth leaf stage; F. Hairs; O. gratissimum L.- G. Second leaf stage; H. Fifth leaf stage; I. Hairs; O. tenuiflorum L.- J. Second leaf stage; K. Fifth leaf stage; L. Hairs.

\section{Acknowledgement}

Thanks are due to Prof. N.D. Paria, Department of Botany, University of Calcutta, Kolkata, India for encouragement. 


\section{References}

Ahammed, J. and Paria, N. 1996. Systematic value of seedling morphology in some Indian Asteraceae. Acta Botanica Indica 24: 49-55.

de Vogel, E.F. 1980. Seedlings of Dicotyledons.Wageningen: PUDOC.

Khanna, K.K., Mudgal, V., Uniyal, B.P. and Sharma, J.R. 1999. Dicotyledonous plants of Uttar Pradesh - A check list. Bishen Singh Mahendra Pal Singh, Dehra Dun, India.

Mustfa, A.E. and Badr, A. 2006. Genetic diversity among Ocimum populations in Egypt as reflected by morphological, seed proteins and Isoenzyme polymorphism. International J. Bot. 2(3): 261-269.

Paton, A.J., Springate, D., Suddee, S., Olieno, D., Grayer, R.J., Harley, M.M., Willis, F., Simmonds, M.S., Powell, M.P. and Savolin, V. 2004. Phylogeny and evolution of basils and allies (Icimeae, Labiatae) based on three plastid DNA region. Mol. Phylogenet. Evol. 31(1): 277-299.

Rao, R.R. 1994. Biodiversity in India (Floristic Aspects). Bishen Singh Mahendra Pal Singh, Dehra Dun, India.

Singh, A.K. 2009. Seedling morphology of some Chenopods - viz. Beta vulgaris L., Chenopodium album L., C. murale L., and Kochia trichophylla Voss. Proc. Nat. Acad. Sci. India Sect. B, 79(III): 271-275.

Singh, A.P., Dwivedi, S., Bharti, S., Srivastava, A., Singh, V. and Khanuja, S.P.S. 2004. Phylogenetic relationships as in Ocimum revealed by RAPD markers. Euphytica 136(1): 11-12.

(Manuscript received on 18 March, 2010; revised on 5 March, 2012) 